KOŚCIÓ£ I PRAWO 10(23) 2021, nr 2, s. 31-44

DOI: https://doi.org/10.18290/kip21102.2

\author{
Justyna Ciechanowska \\ Katarzyna Szwed
}

\title{
PROTECTION OF PERSONAL DATA \\ IN THE CATHOLIC CHURCH IN THE LIGHT \\ OF THE EU REGULATION NO. 2016/67
}

\section{INTRODUCTION}

The Catholic Church and other religious associations operating in Poland have the right to collect and store personal data of their members and other persons who establish legal relations with them. These data should be handled in a way that protects everyone's right to privacy. Currently, modern technologies are more and more frequently used in the processing of personal data by churches and religious associations, therefore that they are required to be highly involved and comply with security rules.

The present paper focuses on the issue of personal data protection in churches and religious associations, including considerations on autonomous models of personal data protection regulated in church acts of internal law, based on the example of the activities of the Catholic Church in Poland.

DR. JUSTYNA Ciechanowska - Institute of Legal Studies, University of Rzeszów; correspondence address: Al. Rejtana 16c, 35-959 Rzeszów, Poland; e-mail: jciechanowska @ur.edu.pl; https://orcid.org/0000-0002-6115-0147

DR. KATARZYNA SzWED - Institute of Legal Studies, University of Rzeszów; correspondence address: Al. Rejtana 16c, 35-959 Rzeszów, Poland; e-mail: szwed@ur.edu.pl; https:// orcid.org/0000-0002-2755-2804

${ }^{1}$ OJ EU L 119.1 of 04.05.2016 [hereinafter: GDPR]. 
The provisions on the protection of personal data were analyzed, i.e. Regulation (EU) 2016/679 of the European Parliament and of the Council of 27 April 2016 on the protection of natural persons with regard to the processing of personal data and on the free movement of such data, and repealing Directive 95/46/EC (General Data Protection Regulation), ${ }^{2}$ national regulations to the extent that they relate to churches and religious associations and their internal regulations regarding the processing and protection of personal data.

The paper aims to present to what extent the Catholic Church is obliged to apply Regulation (EU) 2016/679 of the European Parliament and of the Council of 27 April 2016 on the protection of personal data and on the free movement of such data, and revoking Directive 95/46/EC and what requirements are imposed on its internal regulations and to indicate to what extent personal data protection is its own task.

This article aims to organize the existing knowledge in the above-mentioned research area and to indicate the changes that had to be made in accordance with Article 91 GDPR.

Thus, the amendment to the European law will be presented resulting in the evolution of Polish law, which was also the result of the issuance of the General Decree on the protection of individuals with regard to the processing of personal data in the Catholic Church on March 13, 2018 by the Polish Bishops' Conference. ${ }^{3}$ The content of the decree will also be discussed in order to outline the new legal situation within the institution of the Catholic Church.

\section{STATUS OF THE CATHOLIC CHURCH IN THE REPUBLIC OF POLAND}

The paper aims to analyze the application of Regulation (EU) 2016/679 of the European Parliament and of the Council of 27 April 2016 on the protection of personal data and on the free movement of such data, and revoking Directive 95/46/EC by the Catholic Church, therefore initially, its status and activities need to be defined to answer the above question.

\footnotetext{
${ }^{2}$ OJ EU L 119.1 of 04.05.2016 [hereinafter: GDPR].

3 “Akta Konferencji Episkopatu Polski” 30 (2018), p. 31-45 [hereinafter: PBC].
} 
The rules that define the model of relations between the Republic of Poland and the Catholic Church were included in the Constitution of the Republic of Poland of April 2, 1997, ${ }^{4}$ Concordat between the Holy See and the Republic of Poland of July 28, $1993^{5}$ and the Act of May 17, 1989 on the relationship of the State to the Catholic Church in the Republic of Poland. ${ }^{6}$

In Article 25(3) of the Polish Constitution, a general principle of the system was concluded, defining the institutional relations between the state and churches. It states that "relations between the state and churches and other religious associations are shaped on the basis of respecting their autonomy and mutual independence in their own scope, as well as cooperation for the good of man and common good."

This principle is the overriding principle in relation to the other principles, i.e. equality of churches and religious associations, impartiality of public authorities of the Republic of Poland in matters of religious, worldview and philosophical beliefs and shaping relations between the state and the Catholic Church on the basis of an international agreement concluded with the Holy See and the act, and between the state and other religious associations by means of an act adopted on the basis of agreements concluded between the Council of Ministers and their respective representatives [Stanisz 2015, 166; Idem 2008, 75-77; Pietrzak 2003, 23031]. The principle of the autonomy and independence of each of them in own matters, as well as cooperation between them for the good of man and the common good, means that ecclesiastical authority includes matters of religion and worship, and the incompetence of the state to interfere in the internal affairs of the Church. On the other hand, the state authority covers matters that do not concern religious matters and worship, as well as the incompetence of the Church with regard to the internal relations of the state [Winczorek 2008, 68]. The state's respect for the autonomy of the Church includes recognition of its ability to legislate for itself and govern in internal relations. The independence of the Catholic Church means "spiritual sovereignty, which is the basis of the public-law subjectivity of the Holy See in international relations," which includes the ability to conclude international agreements and diplomatic relations [Krukowski 2000,

\footnotetext{
${ }^{4}$ Journal of Laws No. 78, item 483 as amended.

${ }^{5}$ Journal of Laws of 1998, No. 51, item 318.

${ }^{6}$ Journal of Laws of 2019, item 1347.
} 
108-16; Idem 2008, 74ff]. Confirmation of the above constitutional principle is Article 5 of the Concordat, which states that "By observing the right to religious freedom, the State ensures that the Catholic Church, regardless of the rite, carries out its mission freely and publicly, including the exercise of jurisdiction and administration of its affairs on the basis of canon law."

The relations between the state and the Church should be placed in the formula of the principle of separation, in the version of coordinated separation, which is characterized by the fact that the state provides churches with freedom and independence in the performance of their tasks in the territory of the state. On the other hand, the public-law status of the Church does not limit the independence of the Church from the state, or the state from the Church. This means that the Catholic Church is autonomous in carrying out its tasks [Mojak 2010, 111].

The Church is entitled to full autonomy and independence in the scope which concerns strictly its religious mission and activity. On the other hand, in a situation where the Church conducts e.g. economic activities, it is subject to the provisions of generally applicable law.

In the period preceding the entry into force of the GDPR provisions, the Catholic Church regulated the issues of personal data protection in acts of internal law, based on the above-described principle of autonomy and independence. This was confirmed by the Instruction entitled "Personal data protection in the activities of the Catholic Church in Poland" developed by the Inspector General for Personal Data Protection and the Secretariat of the Polish Bishops' Conference. In accordance with the provisions of the above-mentioned Instruction, the Act on the Protection of Personal Data was applicable to church legal entities in the case of processing the data of persons who did not belong to the Church and who did not maintain permanent contact with it. In relation to the rest of the people, the Church could create its own internal regulations. ${ }^{7}$

One of the most important changes in the history of the development of European and Polish personal data protection law took place on May 24, 2016, when Regulation (EU) 2016/679 of the European Parliament and of the Council of April 27, 2016 on the protection of personal data and on the

\footnotetext{
${ }^{7}$ See https://giodo.gov.pl/data/filemanager_pl/wsp_krajowa/KEP.pdf [accessed: 15.02.2021].
} 
free movement of such data, and repealing Directive 95/46/EC entry into force on and become binding since and then on May 25, 2018. The regulation was adopted in order to unify the standard of personal data protection throughout the European Union.

The above normative act contains a catalogue of requirements that must be met by public administration, entrepreneurs and non-governmental organizations that process personal data of natural entities as a part of their activities. The legislator also included churches and other religious associations in this catalogue, since pursuant to Article 91(1) GDPR "Where in a Member State, churches and religious associations or communities apply, at the time of entry into force of this Regulation, comprehensive rules relating to the protection of natural persons with regard to processing, such rules may continue to apply, provided that they are brought into line with this Regulation" [Bielak-Jomaa and Lubasz 2018, 1112-117].

Churches or religious associations are obliged to comply with the GDPR. However, those churches or religious associations which, at the time of the entry into force of the GDPR, applied internal rules on the protection of personal data, in accordance with Article 91(1) GDPR, they can still apply autonomous, detailed regulations in this regard. These regulations only need to be in line with the GDPR. This means that under Article 91(1) GDPR, the specificity regarding the processing of personal data and their protection is maintained only by those religious associations that apply detailed rules for the protection of individuals with regard to data processing. However, according to Article 91(2) GDPR, churches or religious associations that apply detailed rules for the protection of personal data are subject to the supervision of an independent supervisory authority, which may be an authority separate from the state authority, i.e. the President of the Personal Data Protection Office. ${ }^{8}$ State data protection authorities will have full jurisdiction in this regard, unless a religious association introduces appropriate personal data protection regulations into its internal legal order and an independent institution appointed to supervise compliance with them [Sakowska-Baryła 2018, 63334; Fajgielski 2018, 696-98].

${ }^{8}$ Hereinafter: PUODO. 
The national legislator, in Article 59 of the Act of 10 May 2018, the Personal Data Protection ${ }^{9}$ indicated that the basis for the appointment of separate supervisory authorities was Article 91GDPR, and not Article 25(3) of the Polish Constitution or the acts on religious law. Churches that have introduced internal regulations in the field of personal data protection apply Article 91 GDPR. This means that the protection of personal data is their own task, implemented under the constitutional principle of autonomy and independence, taking into account the requirements set out in Article 91 GDPR [Łukańko 2019, 53-57].

The solution resulting from Article 91 GDPR does not indicate interference of the EU legislator with the national religious law of the Member States. In case before May 24, 2016, the national model in a given Member State would exclude the right of churches to internal regulation in the field of personal data protection or they would not have such a regulation on May 24, 2016, and thus the provision of Article 91 GDPR would not apply, the recital 165 of the General Data Protection Regulation and Article 17(1) of the Treaty on the Functioning of the European Union ${ }^{10}$ may be applied, which guarantees respect for the status of churches and religious associations.

Such a situation occurs i.e. in a constitutional system in which the National Church does not have its own tasks, within which it is able to adopt legislative regulations itself. Then, the organs of state authority enact an appropriate legal act, which contains provisions allowing the church to take advantage of Article 91 GDPR [ibid., 90].

2. INTERNAL REGULATIONS REGARDING THE PROTECTION OF PERSONAL DATA IN THE CATHOLIC CHURCH - GENERAL DECREE ON THE PROTECTION OF INDIVIDUALS WITH REGARD TO THE PROCESSING OF PERSONAL DATA IN THE CATHOLIC CHURCH OF MARCH 13, 2018, ISSUED BY THE POLISH BISHOPS' CONFERENCE

The response of the Catholic Church in Poland to the challenges of the GDPR is the General Decree on the protection of individuals with regard

\footnotetext{
${ }^{9}$ Journal of Laws item 1000.

${ }^{10}$ Hereinafter: TFEU.
} 
to the processing of personal data in the Catholic Church. It is a document that relates only to data processing in the Catholic Church, and not to the Orthodox Church or Protestant Churches, which also have their structures in Poland.

The discussed procedures do not apply to all data processing in the religious sphere (individual religious associations can and should create their own regulations). At the same time, the powers of the Church Data Protection Inspector ${ }^{11}$ appointed by the Polish Bishops' Conference, are limited only to the activities of the Catholic Church (this body will be discussed later). The general decree on the protection of personal data is a document that introduces detailed rules for the protection of personal data in connection with their processing and is adapted to the provisions of the GDPR. The doctrine has expressed different positions regarding its adaptation. P. Litwiński and P. Barta argue that the scope of adjusting internal regulations should apply to all provisions of the GDPR, due to the fact that there is no provision limiting the scope of compliance with the provisions of the GDPR [Litwiński, Barta, and Kawecki 2017, 886]. On the other hand, A. Mezglewski believes that not all the requirements of the EU regulation relating to the rights of persons will apply in the internal law of religious associations. In his opinion, members of the community will be able to waive certain rights resulting from the EU regulation on data processing. In his opinion, domestic law should clearly and precisely define the rights of persons and the procedures for the processing of personal data [Mezglewski 2016, 50]. Referring to the above, it should be noted that persons who join or belong to a religious association assume certain obligations, while agreeing to modify the rules of personal data protection, which are necessary due to the religious doctrine of a given religious association. Thus, the internal regulation of a religious association, and in this case the General Decree on the protection of individuals with regard to the processing of personal data in the Catholic Church, is to apply to all individuals, regardless of their citizenship or place of residence. The decree covers those who are baptized in the Catholic Church and those who have been admitted to it after baptism, including those who have formally made a declaration of will to apostasy, but in accordance with the

${ }^{11}$ Hereinafter: KIOD. 
internal regulations of the Church, and those who maintain constant contact with it.

On the other hand, the subjective scope is defined in Article 4 of this Decree. According to the above-mentioned regulation it applies to public ecclesiastical legal persons which include i.e. Polish Episcopal Conference, metropolises, archdioceses, dioceses, apostolic administrations, parishes, rectors, Caritas Poland and diocesan Caritas, Pontifical Missionary Works, Polish Army Field Ordinariate, chapters, personal parishes, Conference of Major Superiors of Male Orders, Conference of Major Superiors of Female Orders, institutes of consecrated life and associations of apostolic life, provinces of religious orders, abbeys, independent monasteries, religious houses, theological seminaries, the John Paul II Catholic University of Lublin, the Pontifical John Paul II University in Krakow, the Pontifical Faculty of Theology in Poznań, the Pontifical Faculty of Theology in Wrocław, the Pontifical Faculty Theological in Warsaw and its two sections: St. John the Baptist (Collegium Joanneum) and St. Andrzej Bobola (Collegium Bobolanum), Faculty of Philosophy of the Society of Jesus in Krakow (currently its traditions are continued by Ignatianum Academy in Krakow) and canonically erected church scientific, didactic and scientific institutes. Thus, public church legal entities are obliged to apply the above-mentioned Decree in their internal activities, i.e. activities of their own (Article 25(3) of the Polish Constitution), in their field (Article 1 of the Concordat) and their affairs (Article 2 of the Act of 17 May 1989 on the relationship between State and the Catholic Church in the Republic of Poland). This means that these are matters that concern the mission of the Church and are related to the performance of the internal tasks of the Church subject to canon law. However, in mixed church and state matters, the provisions of the Decree and the GDPR will apply [Skonieczny 2018, 78].

The decree consists of a preamble and seven chapters with 44 articles altogether. The preamble indicates the purpose and refers to the existing canonical legal regulations of the Catholic Church and the documents of the Holy See on the protection of personal data. Chapter II describes the principles and standards for the processing of ordinary and special category data by church organizational units. It stipulates i.e. obligation to inform the controller on the processing of data towards the natural person concerned. Chapter III contains the rights of the data subject, among which the decree mentions the right to be informed about data processing, 
to demand rectification of data, to annotate and supplement data, to delete or limit processing. The duties of the data controller contained in Chapter IV of the decree include i.e. obligation to register data processing activities, to ensure the security of their processing. Chapter $\mathrm{V}$ regulates the status of KIOD, the principles of their selection and the scope of its activities. This chapter also includes a solution for additional supervision (regardless of KIOD) over the proper compliance with the provisions on data processing. Such supervision is to be exercised by the diocesan bishop as part of i.e. episcopal visitation, and in religious orders and institutes of consecrated life - by the major superior. Chapter VI deals with the appeal procedure and sanctions for infringement of the provisions of the decree. Sanctions apply to compensation and canonical penal liability, which are described in the relevant canons of canon law.

The Catholic Church processes various personal data of natural persons, i.e. ordinary data and data of a special category (Article 5 PBC). The information about natural persons include i.e. first and last name, address, religion, marital status. Typically, these data are included in datasets, i.e. structured collections of personal data available according to specific criteria. In the activities of the Church, data collections are, in particular, parish registers, the keeping of which is required by common or particular law. These are e.g. books of the baptized, confirmed, First Holy Communion, marriages, deaths, register of parishioners, i.e. parish records [Bączkowicz, Baron, and Stawinoga 1958, 597-615]. Referring to the provisions of the Decree, an important issue are the rights of the natural person whose data is processed. The aim of the EU legislator in the reform was to strengthen the rights of data subjects. The GDPR regulates the system of rights in a consistent manner and gives them great importance. The provisions of the regulation specify the rights of persons, requiring additional diligence on the part of the data controller, e.g. in the field of information, access to data processing, objection to processing, restriction of processing or rectification of data. It was the GDPR that introduced the right to data portability or the right to be forgotten, which had previously been developed by the jurisprudence of the Court of Justice.

The obligation to inform the controller about data processing applies to the information contained in Article 13 and 14 GDPR and to exercise the rights under Article 15-21 GDPR. The general decree of the Catholic Church regulates the above issues in Article 8 and 9 largely refers to the 
solutions adopted in the GDPR. In the case of collecting data from the data subject, the data controller informs this person about the processing, providing information identifying the administrator and allowing them to be contacted, or the contact details of the data protection officer, indicating the purpose of data processing, legal basis for processing, information about recipients and the intention to transfer data to a public church legal person established outside the territory of the Republic of Poland. In addition, the data controller provides information about the period of data processing, information about the right to request access personal data, the right to request rectification, deletion or limitation of processing in accordance with this Decree, and information about the right to lodge a complaint with the Church Data Protection Inspector. In the case of obtaining personal data in a manner other than from the data subject, the provisions of the Decree stipulate that "personal data must remain confidential in accordance with the obligation of professional secrecy provided for by law, including the obligation to maintain the secrecy of confession, in accordance with can. $983 \S 1$ of the Code of Canon Law and can. $773 \S 1$ of the Code of Canons of the Eastern Churches, the secret mentioned in can. 983 $\S 2$ of the Code of Canon Law and can. $773 \S 2$ of the Code of Canons of the Eastern Churches and the pastoral secrecy." This is a reference to Article 14(5)(d) GDPR, which includes the right to confidentiality of data in the event of the obligation of professional secrecy.

However, Article 12 and 13 PBC include the right to rectify and complete the data. The request for rectification of data should be made in writing and submitted to the data controller together with the relevant documents. In case the controller refuses to accept a request for rectification of data, he should notify the applicant of the refusal in writing, who will be able to re-submit the request to the local ordinary or the major superior of the institute of consecrated life or association of apostolic life. Correction of data concerning acts and facts concerning the canonical status of a person can only be made with the permission of the local ordinary or the major superior of an institute of consecrated life or a society of apostolic life.

One of the most important changes introduced by the GDPR was the regulation of the so-called the right to be forgotten. General decree in Article 14, referring to the solutions adopted in the GDPR, grants the right to request the deletion of data. However, this right, in accordance with Ar- 
ticle 14(4) does not apply when it concerns the deletion of data concerning the administered sacraments or otherwise relating to the canonical status of a person. The prohibition of data deletion is due to the nature of the sacraments, which leave an indelible mark on a person and are unique [Janczewski 2014, 36]. The problem of the right to be forgotten concerns people leaving the Church. They very often demand the removal of their personal data from parish data files. To support their request, they state that with their withdrawal from the community of the faithful, the need to process (store) their data has also ceased, which in these circumstances in accordance with the principle of data minimization and the principle of limiting the storage period (Article 5(1)(c) GDPR) - should be removed. In the Church, however, in accordance with para. 10 of the decree on withdrawing from the Church, an annotation about apostasy is entered in the register of baptized persons. The justification for this is that the apostate may, at any time, return to the community of the faithful. In addition, in accordance with para. 15 of the abovementioned decree, the sacrament of baptism is unique and unforgettable. ${ }^{12}$

The general decree also adopted the provisions of Article 18 GDPR regarding the restriction of processing. Pursuant to Article 15(1), the data subject may request the restriction of data processing in a situation where he questions the correctness of personal data - for a period allowing the data controller to check the correctness of such data, when the processing is unlawful, and the data subject objects to the deletion of personal data, requesting instead of restricting their use and when the controller no longer needs the personal data for the purposes of processing.

It should be emphasized that the General Decree on the rights of data subjects does not contain regulations regarding the right to data portability as stipulated in Article 20 GDPR. It seems to be dictated by the inability to change one's religion to another by transferring the data to another Church and making a declaration regarding the acceptance of the new religion. There is also no regulation regarding the right to object under Article 21 GDPR.

${ }^{12}$ Resolution No. 20/370/2015 of the Polish Bishops' Conference of October 7, 2015 on the General Decree of the Polish Bishops' Conference on leaving the Church and returning to the Church community, https://episkopat.pl/wp-content/uploads/ 2016/04/ dekret_ogolny.pdf [accessed: 22.09.2020]. 
The new body established by the Polish Bishops' Conference in connection with the amendment to the protection of personal data introduced by the GDPR is the office - the Church Data Protection Inspector. KIOD is an ecclesiastical office within the meaning of can. 145 of 1983 Code of Canon Law. ${ }^{13}$ It is an independent body that monitors and ensures compliance with the provisions on the protection of personal data within the framework and in accordance with the activities of the Catholic Church and its structures (Article 35(2) of the Decree). KIOD is also a supervisory body for the Catholic Church within the meaning of Article 91(2) GDPR [Bielak-Jomaa and Lubasz 2018, 1115-116]. The term of office of KIOD is four years. Pursuant to Article 37 of the Data Protection Decree, his tasks include supervising compliance with the provisions on the protection of personal data in the Church, disseminating knowledge in this area, advising administrators and processors, informing data subjects about their rights, considering complaints about violation of church data protection regulations and proposing new regulations, including range. The duty of KIOD is also to cooperate with the President of the Personal Data Protection Office. ${ }^{14} \mathrm{He}$ has the right to request explanations from data processors in the Church, as well as to control the correctness of their processing and order controllers to remedy any irregularities found and notify data subjects of data protection breaches (Article 38 of the Data Protection Decree). Pursuant to the provisions of the Decree (Articles 41 and 42), persons whose data are processed unlawfully have the right to appeal to the KIOD or the institution of the Holy See. Violation of the law regarding the processing of personal data may result in canonical sanctions.

\section{CONCLUSION}

The Catholic Church in Poland has adapted its internal law to changes introduced in the protection of personal data in the EU and Polish law. The general decree issued by the Polish Episcopal Conference is a supple-

\footnotetext{
${ }^{13}$ Codex Iuris Canonici auctoritate Ioannis Pauli PP. II promulgatus (25.01.1983), AAS 75 (1983), pars II, p. 1-317.

${ }^{14}$ See Agreement on cooperation and mutual information concluded on 10 May 2019 file://C:/Users/Admin/AppData/Local/Temp/Porozumienie\%20Prezesa\%20UODO \%20z\%20KIOD_10\%20maja\%202019\%20r..pdf [accessed: 23.09.2020].
} 
ment to and more specific to universal canon law. Its purpose is to update, standardize and adjust the rules for the protection of natural persons with regard to the processing of their personal data existing in the Church to the European Union regulation. The creation of its own regulation in the field of personal data protection is primarily aimed at excluding the Church's own activities from the GDPR regulation. The provisions of the decree are an opportunity to increase the level of protection of the personal data of the faithful and to create greater clarity for the legal situation of the subjects of the Church.

\section{REFERENCES}

Bączkowicz, Franiczek, Józef Baron, and Władysław Stawinoga. 1958. Prawo kanoniczne. Podręcznik dla duchowieństwa. Vol. 2. Opole: Wydawnictwo Diecezjalne św. Krzyża.

Bielak-Jomaa, Edyta, and Dominik Lubasz. 2018. RODO. Ogólne rozporzadzenie o ochronie danych. Komentarz. Warszawa: Wolters Kluwer Polska.

Fajgielski, Paweł. 2018. Ogólne rozporzqdzenie o ochronie danych osobowych. Ustawa o ochronie danych osobowych. Komentarz. Warszawa: Wolters Kluwer Polska.

Janczewski, Zbigniew. 2014. "Chrzest." In Wielka Encyklopedia Prawa. Vol. 2: Prawo kanoniczne, ed. Grzegorz Leszczyński, 36. Warszawa: Fundacja "Ubi Societas Ibi Ius".

Krukowski, Józef. 2000. Kościót i państwo. Podstawy relacji prawnych. Lublin: Redakcja Wydawnictw KUL.

Krukowski, Józef. 2008. Polskie prawo wyznaniowe. Warszawa: LexisNexis.

Litwiński, Paweł, Paweł Barta, and Maciej Kawecki. 2017. Rozporzadzenie UE w sprawie ochrony osób fizycznych $w$ zwiazku $z$ przetwarzaniem danych osobowych $i$ swobodnym przeptywem takich danych. Komentarz. Warszawa: Wydawnictwo C.H. Beck.

Łukańko, Bernard. 2019. Kościelne modele ochrony danych osobowych. Warszawa: Wolters Kluwer Polska.

Mezglewski, Artur. 2016. "Perspektywa i zakres implementacji nowych przepisów Unii Europejskiej dotyczących przetwarzania danych osobowych przez związki wyznaniowe." In Ochrona danych osobowych w Kościele, ed. Stanisław Dziekoński, and Piotr Drobek, 36-52. Warszawa: Wydawnictwo UKSW.

Mojak, Ryszard. 2010. “Zasada autonomii i wzajemnej niezależności oraz współdziałania w stosunkach między państwem a Kościołami i innymi związkami wyznaniowymi." In Polskie Prawo Konstytucyjne, ed. Wiesław Skrzydło, 108-11. Lublin: Verba.

Pietrzak, Michał. 2003. Prawo wyznaniowe. Warszawa: LexisNexis.

Sakowska-Baryła, Marlena. 2018. Ogólne rozporzadzenie o ochronie danych osobowych. Komentarz. Warszawa: Wydawnictwo C.H. Beck.

Skonieczny, Piotr. 2018. "Zakres przedmiotowy Dekretu ogólnego KEP z 13 marca 2018 roku w sprawie ochrony osób fizycznych w związku z przetwarzaniem danych osobowych w Kościele katolickim. Prawonoporównawczy punkt widzenia.” Annales Canonini 1:69-86. 
Stanisz, Piotr. 2008. "Naczelne zasady instytucjonalnych relacji państwo-kościół.” In Prawo wyznaniowe, ed. Artur Mezglewski, Henryk Misztal, and Piotr Stanisz, 68-79. Warszawa: Wydawnictwo C.H. Beck.

Stanisz, Piotr. 2015. "Konstytucyjne zasady określające relacje państwa z Kościołami i innymi związkami wyznaniowymi: autonomia i niezależność.” In Katolickie zasady relacji państwo-Kościót a prawo polskie, ed. Józef Krukowski, Mirosław Sitarz, and Henryk Stawniak, 159-85. Lublin: Towarzystwo Naukowe KUL.

Winczorek, Piotr. 2008. Komentarz do Konstytucji Rzeczypospolitej Polskiej z dnia 2 kwietnia 1997 roku. Warszawa: Liber.

\title{
Protection of Personal Data in the Catholic Church in the Light of the EU Regulation No. 2016/67
}

\begin{abstract}
The article deals with the issues of personal data protection in the Catholic Church in Poland. It presents to what extent the Catholic Church is obliged to apply Regulation (EU) 2016/679 of the European Parliament and of the Council of April 27, 2016 on the protection of personal data and on the free movement of such data, and repealing Directive 95/46/EC and what are its requirements to its internal regulations. Reference was also made to the content of the Decree of the Polish Episcopate on the protection of personal data of March 13, 2018.
\end{abstract}

Keywords: personal data; the Catholic Church; RODO; KIOD; PUODO

\section{Ochrona danych osobowych w Kościele katolickim w świetle unijnego rozporządzenia nr 2016/67}

\section{Abstrakt}

W artykule poruszono problematykę dotyczącą ochrony danych osobowych w Kościele katolickim w Polsce. Artykuł prezentuje, w jakim zakresie Kościół katolicki zobligowany jest do stosowania rozporządzenia Parlamentu Europejskiego i Rady (UE) 2016/679 z 27 kwietnia 2016 r. w sprawie ochrony danych osobowych i w sprawie swobodnego przepływu takich danych oraz uchylenia dyrektywy 95/46/WE i jakie wymagania stawia ono jego przepisom wewnętrznym. Odniesiono się również do treści dekretu Konferencji Episkopatu Polski o ochronie danych osobowych z 13 marca 2018 r.

Słowa kluczowe: dane osobowe; Kościół katolicki; RODO; KIOD; PUODO

Informacje o Autorze: DR JUstyna Ciechanowska - Instytut Nauk Prawnych, Uniwersytet Rzeszowski; adres do korespondencji: Al. Rejtana 16c, 35-959 Rzeszów, Polska; e-mail: jciechanowska@ur.edu.pl; https://orcid.org/0000-0002-6115-0147

Informacje o Autorze: DR KATARZYNA SzWED - Instytut Nauk Prawnych, Uniwersytet Rzeszowski; adres do korespondencji: Al. Rejtana 16c, 35-959 Rzeszów, Polska; e-mail: e-mail: szwed@ur.edu.pl; https://orcid.org/0000-0002-2755-2804 